AperTO - Archivio Istituzionale Open Access dell'Università di Torino

A quality control approach to better characterise the spatial distribution of snow depth over New Brunswick, Canada

This is a pre print version of the following article:

Original Citation:

Availability:

This version is available http://hdl.handle.net/2318/1706180

since 2019-07-11T14:56:37Z

Published version:

DOI:10.1002/joc.6166

Terms of use:

Open Access

Anyone can freely access the full text of works made available as "Open Access". Works made available under a Creative Commons license can be used according to the terms and conditions of said license. Use of all other works requires consent of the right holder (author or publisher) if not exempted from copyright protection by the applicable law. 


\title{
A quality control approach to better characterise the spatial distribution of snow depth over New Brunswick, Canada.
}

\author{
Alice Baronetti ${ }^{1}$, Simona Fratianni* ${ }^{1,2}$, Fiorella Acquaotta ${ }^{1,2}$, Guillaume Fortin ${ }^{3}$ \\ ${ }^{1}$ Earth Science Department, University of Turin, Turin, Italy \\ ${ }^{2}$ Centro Interdipartimentale Sui Rischi Naturali in Ambiente Montano e Collinare, University of Turin, Italy \\ ${ }^{3}$ Département d'histoire et de géographie, Université de Moncton, Moncton, Canada
}

\section{Abstract}

The aim of this work is to develop, from a high resolution climate analysis, a quality control standard methodology applied to manual snow cover (HS) series managed by the Snow Survey Database in New Brunswick (Canada). The database collected snow depth data biweekly starting at the end of January until the end of April. A thirty-year (1981-2010) analysis of 60 weather stations belonging to two independent meteorological networks was performed. A quality control of the climatic series was performed to evaluate the homogeneity. Three snow depth climatic areas were defined by means of two geostatistical methods (Kriging and Cluster analyses) applied on monthly snow depth, precipitation and temperature data series. Then, for each cluster, the climatological thresholds that characterise a snow fall event during the cold months were detected. Subsequently, a quality control on the daily snow depth series recorded during the January to April period was performed. For each daily series, outlier values were identified by checking both the sudden day-toay changes and extreme thresholds (95th percentile). The quality control was then carried out to the manual series and the observed doubtful events were compared with the snow depth values recorded in the nearby stations. The results show that for the daily snow depth series, the highest number of suspect events was recorded during the months of March and April, and the analysis also shows that there are rain-on-snow events. As for the manual records, questionable snow depth errors randomly distributed in the series were highlighted. Finally, in order to improve the spatial distribution of stations located in the Canadian territory, the results give evidence that, thanks to the high resolution climatic analysis, the proposed approach provides all the benchmarks required to conduct a quality control of snow depth series in absence of other auxiliary variables.

Keywords: Snow depth, Quality control, Climate, Geostatistical methods, New Brunswick

This article has been accepted for publication and undergone full peer review but has not been through the copyediting, typesetting, pagination and proofreading process, which may lead to differences between this version and the Version of Record. Please cite this article as doi: 10.1002/joc.6166 


\section{Introduction}

The "cryosphere" includes all the frozen portions of the Earth system where water is present in a solid form, such as sea ice, lake and river ice, glaciers, frozen ground (including permafrost), and snow cover (Armstrong and Brun, 2008). Snow cover is one of the main indicators of climate change and is mostly used in order to study the relationship between climate and cryosphere (Mudryk et al., 2017). In the last three decades, the polar and cold regions have experienced the most rapid warming on Earth, especially in the northern hemisphere (Kim et al., 2018). The quick increase of temperature in these regions is part of global warming, with regional amplifications due to the relationships established between land surface temperature, oceanic circulation, glacier fluctuations, snow cover extent and duration as well as atmospheric patterns (Juřicová and Fratianni (2018), Serreze and Barry (2011), Pithan and Mauritsen (2014), and Ballinger et al. (2018) showed that Canada, like many other northern and cold regions, experienced a rapid warming with a temperature increase of approximately $1.5^{\circ} \mathrm{C}$ over the $1950-2010$ period and also a significant statistical decrease in the number of ice days in the 1974-2013 period (Fortin et al., 2017). These changes in Canada's temperature also affected many other climatic variables, such as precipitation (Mekis and Vincent, 2011) and snow cover (Brown and Braaten, 1998; Brown, 2000). The last Intergovernmental Panel on Climate Change (IPCC, 2014) gave evidence that since the mid-20th century, the snow depth in Canada has decreased by $1.6 \%$ per decade. This is significant because changes in the spatial and temporal variability of snow cover in Canada during the winter months can seriously affect water resources in terms of quantity and quality (Serreze et al., 2002; Yang et 1., 2003; Chapin et al., 2005; Allard and Lemay, 2012; Warren and Lemmen, 2014).

Anomalies in the spatial distribution of snow depth over Canada are partially attributed to human activities, such as the increase in the concentration of atmospheric greenhouse gases (Rupp et al., 2013), but several studies also highlight links between oceanic and atmospheric variability and the Canadian climate. For example, Brown (1998) and Shabbar and Khandekar (1996) found a relationship between the El Niño-Southern Oscillation (ENSO) positive mode, the reduction of snow cover, and warmer winter temperatures in central and southern Canada. Wang et al. (2006) also observed that positive phases of the North Atlantic Oscillation (NAO) caused a reduction of winter snow storms which affected the snow cover spatial distribution in the provinces of Quebec and New Brunswick.

It is critical to better understand the relationship between snow depth distribution and climate, especially when it comes to the seasonal snow cover, which plays a complex role in the ecosystem and the ecosphere. New Brunswick is a useful area to study because it is a place where air masses converge, and the large-scale oscillations mentioned above have a considerable and observable

This article is protected by copyright. All rights reserved. 
impact on climate trends including snow distribution and duration (Ballinger et al., 2018). The climate of the province is influenced simultaneously by slow-moving and large disturbances and by smaller and intense depressions (cyclones), it is especially the latter that bring instability and storms. Some of the slow-moving or stationary systems are located in the western part of the country. A high pressure ridge along a north-south axis is often located above the Western Cordillera or the Eastern Pacific. In eastern Canada there is a through (low pressure) located between Hudson Bay, the Great Lakes and the Atlantic Coast. However, for cyclones Conrad (2008) reported in his study that the Maritime regions are mainly affected by four different low pressure systems: Mackenzie Low, Alberta Low, Colorado Low, and Gulf Low. New Brunswick is particularly affected by the Colorado Low, which passes over the North American Great Lakes, bringing heavy snowfall during the winter season to the northern part of the region. Fortin and Hétu (2014) also evidenced that two other low pressure systems can occasionally affect the Atlantic coastal area: Hatteras Low and Great Lakes Low. Due to the formation of a strong gradient, they can cause severe winter conditions (snowstorms and blizzards). In this area also, the combined effect of either low or high pressure systems can induce winter rain-on-snow events and temperatures above the freezing point. Another factor which affects the snow cover variability and trends is the synchrony of the phases of several teleconnection patterns (ENSO, NAO, AO, etc.). In fact, if one is in a negative phase and the others are in a positive phase, this can reduce or cancel the effect of the others. For instance, in North America changes in ENSO which brought to precipitation anomalies, is linked with the alternate phase of the Pacific Decadal Oscillation (PDO). In fact, during the positive phase of the PDO, El Nino events determined a dry condition in winter (Enfield et al., 2001). Identifying trends in snow depth can be a challenge when data series are limited (Kunkel et al., 2016). In the literature, several authors have studied the spatial and temporal evolution of snow cover over Canada (Mekis and Brown, 2010; Vincent et al., 2002; Vincent and Mekis, 2006; Brown and Robinson, 2011; Vincent et al., 2012; Milewska and Vincent, 2016), but in most of these studies, only a few stations from the province of New Brunswick (NB) were included. This study is a contribution to the analysis of the temporal and spatial distribution of winter temperatures, precipitation, and snow cover using NB as a case study. Several studies around the globe express a very high variability in snow depth spatial distribution (Irannezhad et al., 2017; Marcolini et al., 2017; Tedesche et al., 2017; Zhong et al., 2018). This variability depends on many factors such as air temperature and the presence of rainfall before, during, and immediately after a snowfall event. The environment (open field or forested area) can also be a very important factor modifying snow accumulation and redistribution. At the local level, snow deposition and accumulation may further be related to elevation (Mott et al., 2015). Blöschl et al. (1999) show also 
that local winds influence snow depth and they can induce process of relocation and influence the energy exchange and mass exchange over snow. The availability of high quality observations, checked and corrected by errors, is an aspect of fundamental importance for applications in the fields of hydrology and engineering, and in the prevention of natural hazards. Large-scale monitoring and quantifying of snow cover is crucial for assessing climate change and its representation in climate models and for analysing cryosphere-climate feedbacks (e.g., Wegmann et al., 2017). Often, validation of general circulation model (GCM) simulations of snow cover have been hampered by a lack of reliable validation data, particularly snow water equivalent (SWE), which is the main snow cover output generated by GCMs. In New Brunswick in particular, it is fundamental to better calibrate and validate the nival accumulation model and to have a more accurate knowledge of the hydrological balance of the Saint John River, which is subjected to flooding due to ice jams. River ice is present in all Canadian rivers and the period ranges between a few days and several months. The interaction of the ice with the river flow impacts the economy and the ecosystem in different ways. Ice jams form in rivers during the freeze-up and break-up period when the movement of the ice is interrupted by congestion or obstacles. The break-up of the ice can result in extreme events that can determinate floods episodes which damage properties and infrastructure, and disrupt navigation and hydropower production (Olthof, 2017). Every year in New Brunswick, the ice jams cause one third of the floods events, and they are more destructive than open-water floods because they score two thirds of all flood damage. Most of the damage occurs along the Saint John River and its tributaries, where the estimated annual average cost is 60 million US dollars (Beltaos and Burrel, 2002).

In this study we propose, from automatic daily snow depth series (National Climate Data Archive [NCDA] ), a standard methodology of quality control applied to manual snow cover series (Snow Survey Database [SSD]) that are not recorded at daily scale. In fact, because snow depth records can be affected by systematic and random errors due to instrumentation, station relocation, measurement errors (e.g., time of measurement, units of measurement), patchy snow conditions, and so on, several studies were conducted to develop daily snow depth quality control (Brown and Braaten, 1998; Estilow et al., 2015; Acquaotta et al., 2015). In this case, we used biweekly snow depth (SSD) records (taken once per month for January and February and twice per month for March and April), observed by stations located in proximity to the automatic network. This study aims to provide support for the manual validation of nivometric data through the development of a methodology for the identification of suspect data, such as abrupt changes in the thickness of the snowpack, outliers, or improbable values given the seasonality of snowfall. Furthermore, in order to minimise the uncertainty of snow spatial distribution, it is essential to have a high density of snow 
depth records spread all over the study area, in order to improve the density of weather stations on the ground. For this reason, in this paper we collected climatological data from two different meteorological networks (the National Climate Data Archive [NCDA] of Environment Canada and the Snow Survey Database [SSD]).

\section{Study area}

The study area analysed in this case is NB, one of the four Canadian Atlantic provinces (Figure 1). NB is lined on the north by the province of Quebec, and on the east by the Gulf of Saint Lawrence and the Northumberland Strait. In the south-east, the Isthmus of Chignecto connects it to Nova Scotia, and in the west, it is bounded by the state of Maine, in the United States. The province's surface area is about $73,400 \mathrm{~km}^{2}$ and is made up of two main geomorphological areas: mountains and plains. The Appalachian mountain range stretches across the north-central part of the province and the highest elevation is Mount Carleton at $817 \mathrm{~m}$ asl. The south-central part of NB is mostly a plateau covered by forests, and this area is cut in every direction by an extensive river system. The Saint John River is the longest river in NB and flows $673 \mathrm{~km}$, draining, along with its numerous tributaries, the entire north-western, central, and south-central parts of the province. The southeastern corner of NB is a lowland plain bounded by the Bay of Fundy, which features the world's highest tides. Southern NB has a temperate climate and the pluvio-thermal characteristics are mostly affected by influxes of moist Atlantic air that moderate climatic extremes. In contrast, the northern part has a continental climate with long periods of snow cover in the winter due to the cold continental air flow (Sabine et al., 2002; El-Jabi et al., 2016; Mallet et al., 2017).

\section{Dataset and preliminary control}

In this study, we analysed snow depth, temperature, and precipitation series recorded at elevations between 100 and $400 \mathrm{~m}$ asl by 60 ground stations belonging to two independent meteorological networks (Figure 1). These series belong to:

- the National Climate Data Archive (NCDA) of Environment Canada: this database consists of over 450 daily liquid precipitation, temperature, and snow depth historical series, recorded across Canada since the 1900s. Prior to the 1960s, stations were concentrated along the border with the US, and on the west coast of British Columbia. After 1960, the sites were better distributed, including all the stations located in the far northern regions. These records are still quality controlled and they are integrated with a number of statistical analyses and metadata in order to highlight inhomogeneities in the series such as changes in instrumentation and station relocations (Groleau et al., 2007; Wang et al., 2017). As 
concerns snow depth records, they were recorded in inches prior to 1975, and in centimetres after that date.

- the Snow Survey Database (SSD): this data archive is managed by the department of Environment and Local Government of New Brunswick. The snow survey information is used in the forecasting of Saint John River flood events due to snow melt. For this reason, most of the stations are found in the Saint John River Basin. The network consists of approximately 116 sites monitoring snow depth and water equivalent in the provinces of New Brunswick and Quebec and the state of Maine. The collection process is based on a federal sampler. The measurement points are selected on well-drained and totally open or forest (no combinations) exposures. For each measurement point, five or six samples are taken and averaged, in order to have one value for each site. The surveys are done at the end of January, and then every two weeks until the snow melts. The obtained dataset is composed of snow depth values collected six times per year (31 January, 15 February, 28 February, 15 March, 31 March and 15 April) since the beginning of 1954. These data were not subjected to a previous quality control.

In order to have the highest density of ground stations and to create a complete and homogeneous database, the chosen common study period is from 1 January 1981 to 31 December 2010. It was not possible to use the maximum length of records available because starting from the 2010s in New Brunswick, several ground stations were neglected. Afterwards, a preliminary analysis was conducted on the whole dataset, and in this regard, only climatic series with less than $20 \%$ of gaps, galculated over the whole period, and no more than 6 consecutive days without records were analysed (Göktürk et al., 2008; Acquaotta and Fratianni 2014). Subsequently, the snow depth values recorded by the NCDA and the SSD were analysed to remove incorrect data, such as snow data $<0$ cm (Nigrelli et al., 2018; Fortin and Hétu, 2014). Daily snow depth values inferior to $1 \mathrm{~cm}$ were deleted in order to prevent any errors due to the sensitivity of the instrumentation (Wang et al., 2010). In addition, the continuity of the selected daily series was checked and the monthly snow depths were calculated, and months with fewer than $80 \%$ of records were deleted (Isotta et al., 2014; Giaccone et al., 2015). Subsequently, daily series of temperature and rain were checked. For this reason, errors due to data processing such as negative daily liquid precipitation amounts were deleted and both daily maximum and minimum temperatures were set for missing values when the maximum daily temperature is equal to or less than the minimum temperature. Next, temperature and precipitation outliers where identified and flagged. Rainfall record anomalies were observed, for example when the weekly accumulation is transcribed as the value of one day (Acquaotta et al., 2018; Murara et al., 2018). Temperature outliers were observed by means of the standard deviation 
thresholds, and all of the daily temperature data greater or lesser than the $+/-$ fourth standard deviation were considered as potential outliers. The flagged outliers were compared with precipitation and temperature series from neighbouring stations (Klein Tank et al., 2009; Guenzi et al., 2017). A visual control was then performed, and daily precipitation and maximum and minimum temperatures were plotted. The analysis of these plots highlighted outliers and the variance of data (Aguilar et al., 2005). Moreover, daily precipitation values inferior to $1 \mathrm{~mm}$ in the series were deleted to prevent a set of small values that reflected changes in the measuring precision from influencing the recording (Wang et al., 2010).

The data obtained is composed of 60 weather series from 1 January 1981 to 31 December 2010 . The preliminary control, carried out on selected stations, evidenced that no negative snow depth values were observed for the SSD and NCDA networks. Thereafter for the NCDA the quality control has highlighted for each series made of 10857 days of record, an average of 2 days with maximum temperature below minimum and less than a day with negative rainfall. The series also showed continuity for all the climatic variables and over the 1981-2010 period an average of 9\% of gaps was observed for the automatic network, while $15 \%$ of snow depth gaps has been detected for the manual network.

\section{Materials and methods}

\subsection{Spatial distribution}

In order to study the spatial and temporal distribution of precipitation, temperature, and snow depth, a geostatistical approach was adopted. First, for the annual precipitation, mean temperature, and monthly snow depths, a spatial interpolation with a $200 \mathrm{~m}$ resolution was performed on a regular grid, which had the following vertices, expressed in cartographic coordinates: WGS84 UTM-19N: North 5358768 and South 4935492, East 386699 and West 1146613 (Boisvert and Deutsch, 2011). Since the topography is smooth and the sample of points is dense, and the elevation is between 100 and $400 \mathrm{~m}$ asl, the ordinary kriging (OK) method was adopted using the Automap package written in R language (Hiemstra and Hiemstra, 2013). We used OK in this study to estimate the liquid precipitation, temperature, and snow depth amounts in unknown points, based on the spatial relationships among the surrounding stations (Ahmed et al., 2017; Bernhardt et al., 2017).

\subsection{Cluster analysis}

In order to perform the quality control of snow data, the province was divided into three subclimatic areas (or clusters) by a cluster analysis (CA). This approach classifies objects with the same characteristics in the same cluster, while dissimilar objects are assigned to different groups. In literature are described two different type of clustering: hierarchical and non-hierarchical. In the present study, a hierarchical agglomerative cluster analysis was performed for the monthly rain,

This article is protected by copyright. All rights reserved. 
temperature, and snow depth using the Ward.D2 method in the R pvclust package (Baronetti et al., 2018). Ünal et al., (2003) evidenced that the hierarchical clustering is more suitable for climatological data, where their distribution is not a priori assumed. In fact, this approach starts with $\mathrm{N}$ cluster, the minimal distance between the groups is calculated and the two nearest clusters are merged. Subsequently, this step is repeated until only one cluster remains. The R pvclust package described in Suzuki and Shimodaira (2015), tests the significance of each group; in fact, the cluster analysis output is a dendrogram with a confidence $\mathrm{P}$-value at each node expressed in percentage. The P-values ranges between $0 \%$ and $100 \%$ and for clusters with p-values above 0.95 , the hypothesis that "the cluster does not exist" is rejected with a significance level of 0.05 . In this regard, all groups with a p-value above $95 \%$ are considered clusters. The climatic analysis was then performed for each area, in which the annual range of liquid precipitation, temperature, and snow depth for the cold season months was calculated. The number of rainy days with precipitation $\geq 1$ $\mathrm{mm}$, the liquid precipitation density, and the number of snowing days with snow $\geq 1 \mathrm{~cm}$ were also detected. In order to perform the quality control, the threshold of daily maximum and minimum temperatures and rain amounts that characterise a snowfall event were calculated for each winter month (Terzago et al., 2012; Fratianni et al., 2015).

\subsection{Quality control}

Finally, the quality control on the daily snow depth series recorded during the January to April period was performed for each climate area. For each cluster, the daily snow depth thresholds that characterise potential snow depth outliers were identified. The thresholds by percentile were galculated on a daily scale and the outliers were individuated. In this regard, all the daily values above the 95th percentile were considered outliers (Acquaotta et al., 2016). Then, once the daily thresholds were calculated, the extreme events recorded in each series were detected, and in order to establish if these detected events were suspicious or wrong data, the maximum and minimum temperatures and rainfall observed during the analysed events were compared with daily precipitation and temperature thresholds observed during a snowfall event, as previously defined (Fortin, 2010). Afterwards, since snow has a high variability, sudden day-to-day changes in snow depth $(\Delta \mathrm{HS})$ between the questionable event and the previous day were also checked. The highest annual snow depth record observed during the 1981-2010 period was analysed for each snow series, and a $\Delta$ HS threshold of $45 \mathrm{~cm}$ was established (Kelly et al., 2003; Durre et al., 2010). Finally, the detected daily snow depth threshold $\left(95^{\text {th }}\right.$ percentile) was applied to the manual SSD snow depth series in order to check for any systematic and random errors, and the outliers were highlighted. Moreover, the under control snow depths were compared with snow depths observed in the nearby stations, and a $30 \mathrm{~cm}$ threshold was established (Goodison et al., 1978; Hiemstra et al., 2006).

This article is protected by copyright. All rights reserved. 
A second step of quality control was carried out on the manual series, comparing the temperature and liquid precipitation values recorded in the surrounding stations during the analysed events with daily precipitation and temperature thresholds characterising a snowfall episode. In this study, the selection of the nearby stations was based on four parameters: the difference in elevation $(<200 \mathrm{~m})$, the distance $(20 \mathrm{~km})$, the same exposure, and the same position area (open, mixed or forest, Biancotti et al., 2005; Acquaotta et al., 2016). Due to the difficulty of snow cover accuracy measurement, solid precipitation data are still beset with significant errors. Within the Canadian literature, the studies of Folland, (1988), Yang et al. (1999), Mekis and Vincent (2011), and Rasmussen et al. (2012) found an underestimation of daily snow depth records in wintertime because of the deflection of snowflake trajectories by effect of the airflow. In this study, we associated a percentage of underestimation to the daily snow depth threshold. This was calculated for each cluster as the maximum difference between the cleaned snow depth values recorded in the automatic series and the amount of snow depth observed in the surrounding corrected manual stations.

A flowchart of the methodology is provided in the supporting information section (Figure S1)

\section{Results}

\subsection{Spatial distribution}

The spatial interpolation of annual rain and mean temperature (Figure 2) during the cold season months of the 1981-2010 period shows that the climate of New Brunswick is mostly influenced by INo different air masses, and a clear north to south gradient was observed in liquid precipitation, temperature, and snow depth (figure 3). The climate of the south-west central and coastal area is mitigated by the effects of the moist and mild Atlantic air; this area is the warmest and the rainiest with winter precipitation over $350 \mathrm{~mm}$ and mean annual temperature between $-3{ }^{\circ} \mathrm{C}$ and $-1{ }^{\circ} \mathrm{C}$. Furthermore, a dry and cold area exists in the north-western part of the region, near the border with the province of Quebec and the state of Maine. Here, the climate is mostly influenced by dry and cold continental air masses, and recorded annual winter precipitation $100 \mathrm{~mm}$ below that of the southern region, while the mean temperature is below $-5^{\circ} \mathrm{C}$. A central and transitional area in the central north-east forested plateau of NB is also evident. Annual winter precipitation amounts are of 250-300 $\mathrm{mm}$ and the mean temperature is between $-5{ }^{\circ} \mathrm{C}$ and $-3{ }^{\circ} \mathrm{C}$.

The spatial snow depth interpolation developed for each cold period month indicates a high correlation with precipitation and temperature distribution, featuring a north to south gradient (Figure 3). Figure $3 a$ indicates that in January, similar values of snow depth $(45-50 \mathrm{~cm})$ are observed for all the regions, although slightly higher amounts are recorded in a few stations in the 
north-western region (50-55 cm). During February (Figure 3b) and March (Figure 3c), the greatest amounts of snow depth are reached, and three different areas are then well defined: $50-65 \mathrm{~cm}$ in February and 45-55 cm in March are recorded in the driest and coldest part of the north-west. Meanwhile, 35-40 cm are observed in February and 15-25 cm in March are observed in the warmest and wettest part of the south-east. Between the south and north areas, a transitional zone is detected and $40-50 \mathrm{~cm}$ of snow depth is observed in February and 25-40 cm in March. The spatial distribution during April (Figure 3d) shows a decrease of snow depth to less than $10 \mathrm{~cm}$ in southern NB while at the same time, in the northern part, the snow depth was much more considerable at 20$30 \mathrm{~cm}$.

\subsection{Cluster analysis}

The spatial distribution of rainfall, temperature, and snow depth was improved through the cluster analysis (Figure 4). The application of this method delineated the three most significant climatic areas in NB. The climate analysis shows that the rainiest and warmest area is CA2 (Table 1), which includes the stations located in the south-central. This area is mostly influenced by air masses from the North Atlantic Ocean and the annual maximum temperature observed during the cold period is $1.8{ }^{\circ} \mathrm{C}$ while the minimum is $-8.5{ }^{\circ} \mathrm{C}$. The annual winter precipitation is between $464.2 \mathrm{~mm}$ and $329.0 \mathrm{~mm}$ with an annual precipitation density of $9.5 \mathrm{~mm} /$ day, and the snow depth is between 12.6 $\mathrm{cm}$ and $25.8 \mathrm{~cm}$. The number of snowy days recorded during the cold months is reported in Table 1; the analysis indicates that in January and February, six days are observed, compared to five in March and two in April. Table 2 shows that in CA2, a snowfall event is characterised by a daily naximum temperature between $-1.5^{\circ} \mathrm{C}$ and $-6.5{ }^{\circ} \mathrm{C}$ in January and between $-1.0{ }^{\circ} \mathrm{C}$ and $-4.5{ }^{\circ} \mathrm{C}$ in February, and the observed precipitation is solid. In fact, no rainfall was recorded during these two months. Considering that in March and April, the maximum temperatures recorded during a snowfall are above zero (Table 2), a snow melt due to the presence of liquid precipitation could occur.

The driest and coldest area, CA1 (Table 1), is located near the mountain chain in the north-west; the annual winter precipitation is between $389.8 \mathrm{~mm}$ and $234.7 \mathrm{~mm}$ and the annual precipitation density is $7.7 \mathrm{~mm} /$ day. In this area, the highest amounts of snow depth are recorded, and they are between $60.3 \mathrm{~cm}$ and $70.9 \mathrm{~cm}$. The climatic characterisation also shows that the number of snowy days is eight in January, decreasing to six in February, and five in March. The lowest values are recorded in April, with three days (Table 1). The annual cold period maximum temperature recorded in this area is $-1.1{ }^{\circ} \mathrm{C}$ and the minimum is $-12.3{ }^{\circ} \mathrm{C}$. In the coldest area, the climate analysis also demonstrated that daily snowfall events are characterised by maximum temperatures below zero during January (-

This article is protected by copyright. All rights reserved. 
$6.7{ }^{\circ} \mathrm{C}$ and $\left.-13.0^{\circ} \mathrm{C}\right)$, February $\left(-4.0^{\circ} \mathrm{C}\right.$ and $\left.-9.0^{\circ} \mathrm{C}\right)$, and March $\left(-2.3{ }^{\circ} \mathrm{C}\right.$ and $\left.-3.5^{\circ} \mathrm{C}\right)$, while in April, the temperature is slightly under or above the freezing point $\left(1.5^{\circ} \mathrm{C}\right.$ and $\left.-1.3{ }^{\circ} \mathrm{C}\right)$.

Just as in CA2, rain was absent throughout all the months (Table 2). The CA3 (Table 1) covers the Central Highlands and the results are between those of CA1 and CA2. Rainfall amounts between $331.3 \mathrm{~mm}$ and $251.0 \mathrm{~mm}$ are recorded, and the annual precipitation density is $9 \mathrm{~mm} /$ day, while the snow depths are between $20.5 \mathrm{~cm}$ and $60.5 \mathrm{~cm}$. The number of snowy days in the transitional area is seven days in January, five days for both February and March, and three days in April. The cold season maximum temperature recorded in this area is $0.1{ }^{\circ} \mathrm{C}$, while the minimum is $-10.8{ }^{\circ} \mathrm{C}$. The climate analysis also highlighted that in CA3, daily snowfall events are characterised by maximum temperatures below zero in January $\left(-3.6{ }^{\circ} \mathrm{C}\right.$ and $\left.-8.2{ }^{\circ} \mathrm{C}\right)$, February $\left(-2.0{ }^{\circ} \mathrm{C}\right.$ and $\left.-8.0{ }^{\circ} \mathrm{C}\right)$, and March $\left(-0.3{ }^{\circ} \mathrm{C}\right.$ and $\left.-3.0^{\circ} \mathrm{C}\right)$, while in April, the maximum temperature is above zero $\left(3.0^{\circ} \mathrm{C}\right.$ and $0.0{ }^{\circ} \mathrm{C}$ ). Like for $\mathrm{CA} 2$, no rain was recorded during this period (Table 2).

\subsection{Quality control}

Table 2 presents the daily snow depth thresholds for extreme events $\left(95^{\text {th }}\right)$ observed for each cold season in the three areas. For the daily automatic snow depth, the quality control indicates no outliers in January and February, but in March, $40 \%$ of the observed outliers were flagged as suspicious events for CA2 and 23\% for CA3. This value increased in April, with $33.7 \%$ of outliers flagged as suspicious in CA2 and $22.7 \%$ in CA3.

The quality control performed on the manual series highlighted that the analysed episodes could be due to random errors in the measurement and they were flagged and replaced with NA. In fact, in January, no outliers were detected in the south-eastern (CA2) and north-western zones (CA1), but $25 \%$ of all the outliers were replaced with NA in the central transitional area (CA3). On the other hand, in February, $30 \%$ of the outliers were flagged in the CA1. In March, the $21 \%$ of the observed outliers were flagged as errors in CA1 and $16 \%$ in CA3. Finally, the quality control performed in April in CA3 has led to $10 \%$ of outliers being replaced with NA.

\subsubsection{Study case}

The quality control by means of percentiles was applied to all sets of weather stations, but we decided to give a detailed report of the results of one automatic station and one manual station located in CA3. The selected automatic station is Woodstock $(611932,5113957$ WGS84 UTM$19 \mathrm{~N})$. The station presents all the required features for the application of the quality control. Indeed, it is situated in Carleton County, in a homogeneous area along the border with the forest on the right bank of Saint John River, at $153 \mathrm{~m}$ asl, and it is surrounded by both automatic and manual neighbouring stations. The first step of quality control indicates that no snow depth values below zero were observed, and the series shows continuity in the snow depth amounts over several years 
with a $6 \%$ of gaps. The quality control carried out in January shows that for the CA3 in New Brunswick, the snow depth threshold that characterises a possible outlier is $85 \mathrm{~cm}$ (Table 2). For the Woodstock station, the application of the snow depth threshold highlighted four outliers in January. The results of the quality control showed that these episodes are extreme events and they were not flagged. In fact, Table 3 highlighted that for all the episodes, the observed climatic conditions suggested that these events are correct, in fact both maximum and minimum temperatures recorded during the extreme events are in the daily range that describes a snowfall event, the liquid precipitation is zero and the $\Delta \mathrm{HS}$ is below the threshold of $45 \mathrm{~cm}$. As concerns the quality control performed in February, the detected threshold for an outlier event recorded in CA3 is $90 \mathrm{~cm}$ (Table 2) and three events are observed for the Woodstock station. The results of the quality control show that no one of the highlighted episodes has been flagged as error. The quality check applied in March demonstrates that the snow depth daily threshold recorded in CA3 is $85 \mathrm{~cm}$ and four outliers are detected in the Woodstock snow cover series (Table 2). The quality control indicates that one of the four outliers is a dubious snow depth event which is recorded 9 March 2003. Unlike in January and February, the climatic conditions recorded during this episode diverge from what is recorded during a snowfall event. In fact, a liquid precipitation of $2 \mathrm{~mm}$ was recorded (Table 3) and the maximum temperature of $3.0^{\circ} \mathrm{C}$ is above the temperature range threshold $\left(-0.3{ }^{\circ} \mathrm{C}\right.$ and $-3.0{ }^{\circ} \mathrm{C}$, Table 2) was observed. Specifically, the presence of a maximum temperature above $0{ }^{\circ} \mathrm{C}$ supposes a melting process in the snow cover, which had increased by $2 \mathrm{~cm}(\Delta \mathrm{HS})$. Finally, for April in CA3, the detected daily snow depth threshold is $55 \mathrm{~cm}$, and for the Woodstock station, there are three outliers, and one of which was t flagged as suspicious. In fact, for the 1 April 2008, the climatic conditions recorded diverge from what is observed during a snowfall event (Table 3). Consequently, during this event, a liquid precipitation of $9.5 \mathrm{~mm}$ was recorded and the maximum temperature reached was $8.5^{\circ} \mathrm{C}$, which is $5.5^{\circ} \mathrm{C}$ above the temperature range of a snowfall event (Table 2). The event was flagged suspicious, because even if the maximum temperature observed the previous day was above $0{ }^{\circ} \mathrm{C}$ (Table 2) and a snow cover melt was assumed, an increase of snow depth of $8 \mathrm{~cm}$ was recorded.

Subsequently, the quality control of a manual series was performed. The selected station is Becaguimec (631080, 5121354 WGS84 UTM-19N). It is located in proximity to the previously quality controlled Woodstock station, in a homogeneous area of Carleton County, in the forest on the right side of Saint John River, at $137 \mathrm{~m}$ asl. The quality control of this station was carried out by means of the observation of three nearby stations: Woodstock, Gibson Millstream, and Mapleton. Table 4 reports the characteristics of each station and shows that all the stations have the same exposure, the difference of elevation $(80 \mathrm{~m}$ ) is below the fixed threshold of $200 \mathrm{~m}$, and the distance 
to Becaguimec is below $20 \mathrm{~km}$. Also, all the stations are situated in the forest of Carleton County on the right side of the Saint John River. The quality control on the manual series was carried out, identifying the suspect events with the application of the daily snow depth thresholds previously detected. In January, two outliers were highlighted. The quality control gives evidence that no of them were flagged as error. Indeed, the snow depth difference with the nearby stations is below the threshold of $30 \mathrm{~cm}$ (Table 5), and the values of liquid precipitation and temperature recorded by the two automatic stations (Woodstock and Mapleton) suggest that a snowfall event was recorded (Table 6). Similarly to January, no outliers were flagged as error in February and March. In April, the quality control highlighted four outliers, and two of them were marked as error and replaced with NA: 14 April 1995 with $69.6 \mathrm{~cm}$ and 14 April 2008 with $73.7 \mathrm{~cm}$. Indeed, the comparison of the snow depth values recorded during the two episodes with those of the surrounding stations (Table 5) expresses a difference in snow depth of more than $30 \mathrm{~cm}$. On 14 January 1995, the observed event was $69.6 \mathrm{~cm}$, but in Woodstock, Mapleton, and Gibson Millstream, $0 \mathrm{~cm}, 5 \mathrm{~cm}$ and $30.1 \mathrm{~cm}$ were recorded, respectively. The climatic conditions observed in Table 6 also show that during the detected episode, in the two automatic series (Woodstock and Mapleton), maximum and minimum temperatures were above the daily snowfall threshold in March (Table 2). For instance, on 14 April 1995 in Woodstock, a maximum temperature of $4.5{ }^{\circ} \mathrm{C}$ was recorded instead of the fixed threshold (Table 1) and a minimum temperature of $2.7^{\circ} \mathrm{C}$ above the calculated range was observed (Table 2). Also, in both the automatic stations, a liquid precipitation of 13.6-13.2 mm was individuated. The detection of the two errors did not influence the snow depth trend (-0.007), but led to changes in the monthly snow depth amount, affecting the results of the climatic analysis. In fact, before the QC in April, $27.4 \mathrm{~cm}$ were recorded, as opposed to $24.5 \mathrm{~cm}$ after the QC.

Once the quality control was performed on all the dataset, the percentage error associated to the automatic station for each climatic area was calculated. The results of this study confirmed the north to south gradient, and as concerns the transitional area (CA3), the results highlighted that $32 \%$ of error in the measurement of extreme events could be applied to the fixed threshold. For instance, for Woodstock, the comparison with the surrounding stations indicates that with Becaguimec, the maximum percentage error is recorded on 15 March 1994 with 25.1\%. The highest error is recorded in the northern area (CA1) with 35\%, and the lowest is recorded in the southern part (CA2) with $15 \%$. These results suggest a strong relation between the two different air masses that affect the study area. In particular, the cold and dry continental airflow determined the highest uncertainty in the record of snow depth values.

\section{Discussion}

This article is protected by copyright. All rights reserved. 
In this study, a quality control approach for snow depth data was performed, and the results indicate that the proposed quality control is mostly based on a high-resolution climate analysis. The spatial and temporal distribution of rainfall, temperature, and snow depth during the cold months was analysed and the daily conditions that characterise a snowfall event were estimated and used as thresholds. From the spatial analysis, as observed by Vincent et al. (2015) and El-Jabi et al. (2016) for all the Canadian territory, a north to south climatic gradient was displayed due to two airflows: continental and Atlantic. Those effects determined the detection of three different climatic subareas. First, there is the south-central area, which according to the Groenewoud classification (1984) is the south-central territory of New Brunswick, and corresponds to the east coast and the Southern Uplands. This is the warmest and rainiest sector of all New Brunswick, and low values of snow depth observed are probably linked to the positive mode of the North Atlantic Oscillation (NAO) that affects the greater part of southern Canada (Bonsal et al., 2001; Brown, 2010). As for the northern area (CA1), it is influenced by the dry and cold continental air mass and it is characterised by low temperature and liquid precipitation rates. In this area, the highest amount of snow depth was observed. In fact, Zhang et al. (2007), Min et al. (2008), Brown (2010) and Fortin and Hétu (2014) found an increase of snow cover in areas around the $55^{\circ} \mathrm{N}$, which is linked to NAO's negative mode. The climatic characterisation also demonstrates that even if different amounts of snow depth in the three climatic areas are recorded, the number of snowy days recorded in the three clusters are almost the same. In particular, the snow fall events are more frequent during January and February, while the lowest amounts are observed in April.

In the literature, several methods of quality check of snow cover values are described. For instance, Hantel et al. (2000), Laternser and Schneebeli (2003), Fazzini et al. (2004) and Castebrunet et al. (2012) developed different quality controls for the daily snow cover series located respectively in Austria, Switzerland, Italy, and France. All the methodologies are established in order to detect any error and homogeneities in the daily snow depth series without the observation of other climatological variables, detecting several skiability thresholds. As concerns Canada, Brown and Braaten (1998) developed, from daily snow depth series, a procedure of quality control at daily and monthly scales which is actually used by the Canadian government. The method is based on the daily comparison of snow cover values and the observation of other climatic variables. Unlike from what is observed in the literature, our proposed methodology of quality control from daily snow depth series permits to check the goodness of manual snow cover series with few records per year. The application of the procedure of quality control carried out on the daily snow depth values highlighted the importance of previously developed climatic characterisation. In fact, the application of the daily snow depth thresholds gives evidence of several outliers, but the 
comparison of liquid precipitation and temperature observed during the episodes with the daily climatic thresholds detected during a snowfall event was useful to observe that in January and February, none of them were flagged as suspicious and they were considered as extreme episodes. In fact, in January, the detailed analysis of the monthly snow cover distribution shows that in all of the New Brunswick territory, the same snow depth values were reached. In their studies, Fortin (2010) and Sospedra-Alfonso et al. (2014) explained that this phenomenon is linked with the snow cover formation, because seasonal snow covers normally start to settle down in January from a series of winter storms poor in liquid precipitation occurring over the whole area, but the spatial distribution is modified in the following months by the action of several climatic events, such as freeze-thaw cycles, heavy snowfalls or rain-on-snow events that can alter the results in different areas. As concerns March and April, the analysis indicates that all the highlighted episodes could not be considered as errors. In fact, we assume that they were snow mixed with rain events coherent with the measurements recorded in the neighbouring stations, that apparently could be considered outliers. In this regard, they were flagged as doubtful. In the literature, Diro et al. (2018) explains the link between snow mixed with rain episodes and negative ENSO values as detected by the Climate Prediction Centre (CPC) in 1982, 1995, 2001, and 2008. According to the international literature (Compo et al., 2001; Eichler and Higgins, 2006; Zhang et al., 2014; Liu et al., 2017), these periods are characterised by high snow depth values due to the effects of La Niña, and the presence of rain during snowfall events can produce snow melt and ice jams during the months of March and April (Lee et al., 2018). The quality control performed on the manual series, due to the application of previously observed daily snow depth thresholds and the comparison with the values recorded in the surrounding stations, highlighted that the developed approach was able to detect random errors in the manual series with few records per year. Unlike what was observed for the automatic series, the detected episodes were flagged as errors and they were replaced with NA (missing). This hypothesis was further confirmed by the "Modeled Snow Depth Forecast" developed by the National Operational Hydrologic Remote Sensing Center (https://www.nohrsc.noaa.gov/interactive/html/map.html), that did not record extreme snow depth episodes in the detected days. These episodes are also not coherent with the snow depth values recorded by the surrounding stations. Finally, as shown in this study, the measurement of snow data depends on the different techniques adopted. Solid precipitation is particularly difficult to measure accurately, in fact several authors have analysed the problem of the underestimation of automatic stations in Canada. Goodison (1978) found an underestimation of 30\% over all of Canada, while Wang et al. (2017) documented how Environment and Climate Change Canada developed the adjusted daily rainfall and snowfall dataset. The adjustment of daily snowfall data consists in the 
conversion of snowfall to its water equivalent using a previously detected snow water equivalent ratio map for Canada. As observed in our study, results show that the highest underestimation was observed in the northern part of Canada (more than 25\%), against less than 10-15\% in the south of Canada.

\section{Conclusion}

Among the national and international papers focused on the quality control of daily snow data series using the comparison with several variables such as temperature, precipitation, and wind, this study proposes to develop and test a new procedure that permits to check the goodness of snow depth series collected at different time scales. Due to the lack of snow cover information and the low density of ground stations in New Brunswick, the application of this method makes it possible to not only use the quality checked daily values managed by Environment and Climate Change Canada, but also analyse snow depth series located in remote areas. In fact, the application of the described methodology, through the detection of sub-climatic areas, allows us to identify suspicious snow depth events without a high density of nearby stations. The described procedure also permits to increase the spatial resolution of snow depth values with the observation of snow cover data collected not only by the network managed by Environment and Climate Change Canada, but also by public and private networks, such as the Snow Survey Database, with few records per year. The results also demonstrate that this methodology is more suitable for the regions as the Appalachian mountain chain in North America, the Scandinavian Mountains, the Ural Mountains in Russia, and the Cambrian Mountains in Scotland with low elevation ranges and smooth surface. The benefits of this study are numerous. For example, in New Brunswick, a better understanding of the snow distribution is important for the management of water resources, whether it be for the forecasting of spring floods or for the hydropower production. The proposed method is also easily transferable to neighbouring provinces (Nova Scotia, Prince Edward Island, Quebec) or elsewhere, especially where measurement networks are well established.

Future work will also go into testing this methodology for European study areas such as the Alps mountain range, where a dense automatic network managed by public and private authorities is available. Performing this methodology in these areas, which are largely devoted to winter tourism due to the high presence of ski resorts, can contribute to a better understanding of spatial and temporal evolution of snow cover as an indicator of climate change.

\section{Acknowledgements}

The authors would like to thank Nadine Caissie Long of the Department of Environment and Local Government of New Brunswick for the SSD database and all the information related to 
measurement, location, and collection of data. Thanks are also due to the Government of Canada, to Environment Canada, for the NCDA database. Finally, thanks to the reviewers for the comments that have improved the quality of the manuscript.

\section{Supporting information}

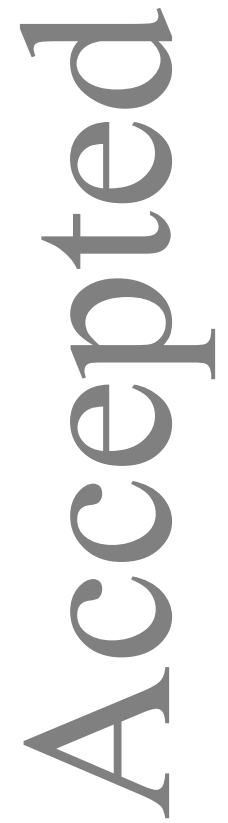

This article is protected by copyright. All rights reserved. 


\section{References}

Acquaotta, F., Faccini, F., Fratianni, S., Paliaga, G. and Sacchini, A. (2018) Rainfall intensity in the Genoa Metropolitan Area: secular variations and consequences. Weather, 73 (11), 356-362. https://doi.org/ 10.1002/wea.3208.

Acquaotta, F., Fratianni, S. and Venema, V. (2016) Assessment of parallel precipitation measurements networks in Piedmont Italy. International Journal of Climatology, 36(12), 39633974. https://doi.org/10.1002/joc.4606.

Acquaotta, F., Colombo, N., Fratianni, S., Romeo, V. and Barbero, S. (2015) Preliminary Results of a Comparison Study Between Two Independent Snow Networks in North-Western Italian Alps (Piemonte Region). In Engineering Geology for Society and Territory-Volume 1 (pp. 113-116). Springer, Cham. https://doi.org/10.1007/978-3-319-09300-0_22

Acquaotta, F. and Fratianni, S. (2014) The importance of the quality and reliability of the historical time series for the study of climate change. Revista Brasileira de Climatologia 14, 20-38.

Aguilar, E., Peterson, T.C., Obando, P.R., Frutos, R., Retana JA, Solera, M., Soley, J., Garcia, I.G., Araujo, R.M. and Santos, A.R. (2005) Changes in precipitation and temperature extremes in Central America and northern South America 1961-2003. Journal of Geophysical Reswangearch: Atmospheres, 110(D23107). https://doi.org/10.1029/2005JD006119.

Ahmed, K., Shahid,. S., Chung, E.S., Ismail, T. and Wang, X. (2017) Spatial distribution of secular trends in annual and seasonal precipitation over Pakistan. Climate Research 74, 95-107. https://doi.org/10.3354/cr01489.

Allard, M. and Lemay, M. (2012) Nunavik and Nunatsiavut: from science to policy. An Integrated Regional Impact Study (IRIS) of climate change and modernization. ArcticNet Inc., Quebec. http://www.arcticnet.ulaval.ca/pdf/media/iris_report_complete.pdf. Accessed Dec 2018.

Armstrong, R.L. and Brun, E. (2008) Snow and climate. Physical Processes, Surface Energy Exchange and Modeling. Cambridge University Press, Cambridge, UK.

Ballinger, T.J., Rohli, R.V., Allen, M.J., Robinson, D.A. and Estilow, T.W. (2018) Half-century perspectives on North American spring snowline and snow cover associations with the PacificNorth American teleconnection pattern. Climate Research, 74(3), 201-216. https://doi.org/10.3354/cr01499. 
Baronetti, A., Acquaotta, F. and Fratianni S. (2018). Rainfall variability from a dense rain gauges network in North-West of Italy. Climate Research 75(3):201-213. https://doi.org/10.3354/cr01517.

Beltaos, S., \& Burrell, B. C. (2002). Extreme ice jam floods along the Saint John River, New Brunswick, Canada. Iahs Publication, 9-14.

Bernhardt, J., Carleton, A. M. and LaMagna, C. (2017) A Comparison of Daily Temperature Averaging Methods: Spatial Variability and Recent Change for the CONUS. Journal of Climate, 31(3), 979-996. https://doi.org/10.1175/JCLI-D-17-0089.1.

Biancotti, A., Destefanis, E., Fratianni, S. and Masciocco, L. (2005) On precipitation and hydrology of Susa Valley (Western Alps). Geografia Fisica e Dinamica Quaternaria, 8, 51-58.

Boisvert, J.B. and Deutsch, C.V. (2011) Programs for Kriging and Sequential Gaussian Simulation with Locally Varying Anisotropy Using non-Euclidean Distances. Computers and Geosciences, 37, 495-510. https://doi.org/10.1016/j.cageo.2010.03.021.

Blöschl, G., Piock-Ellena, U., Merz, R. and Gutknecht, D. (1999) Prozeßorientierte Regionalisierung von Hochwässern. Fachgebiet Wasserbau und Wasserwirtschaft Universität Kaiserslautern-Berichte 9, 267-285.

Bonsal, B.R., Shabbar, A. and Higuchi, K. (2001) Impacts of low frequency variability modes on Canadian winter temperature. International Journal of Climatology, 21, 95-108. https://doi.org/10.1002/joc.590.

Brown, R. D. and Robinson, D. (2011) Northern Hemisphere spring snow cover variability and change over 1922-2010 including an assessment of uncertainty. Cryosphere 5, 219-229. https://doi.org/10.5194/tc-5-219-2011.

Brown, R., D., (2010) Analysis of snow cover variability and change in Quebec 1948-2005. Hydrological Processes. 24, 1929-1954, https://doi.org/10.1002/hyp.7565.

Brown, R.D. (2000) Northern Hemisphere snow cover variability and change, 1915-97. Journal of Climate, $\quad$ 13(13), 2339-2355. https://doi.org/10.1175/15200442(2000)013<2339:NHSCVA>2.0.CO;2.

Brown, R.D. and Braaten, R.O. (1998) Spatial and temporal variability of Canadian monthly snow depths, $\quad$ 1946-1995. Atmosphere-Ocean, 36-54. https://doi.org/10.1080/07055900.1998.9649605 
Brown, R.D. (1998). El Niño and North American snow cover. Proc. 55th Eastern Snow Conference, Jackson, NH, 165-172.

Castebrunet, H., Eckert, N. and Giraud, G. (2012) Snow and weather climatic control on snow avalanche occurrence fluctuations over $50 \mathrm{yr}$ in the French Alps. Climate of the Past, 8, 855-875. https://doi.org/10.5194/cp-8-855-2012

Chapin, F.S., Sturm, M., Serreze, M., McFadden, J., Key, J., Lloyd, A. and Welker, J. M. (2005) Role of land-surface changes in Arctic summer warming. Science, 310, 657-660. https://doi.org/10.1126/science.1117368.

Compo, G.P., Sardeshmukh, P.D. and Penland, C. (2001). Changes of sub seasonal variability associated with El Niño. Journal of Climate, 14(16), 3356-3374. https://doi.org/10.1175/15200442(2001)014<3356:COSVAW>2.0.CO;2.

Conrad, C. (2008) Severe and Hazardous Weather in Canada: The Geography of Extreme Events. Oxford University Press: Toronto, Canada.

Diro, G.T., Sushama, L. and Huziy, O. (2018) Snow-atmosphere coupling and its impact on temperature variability and extremes over North America. Climate Dynamics, 50(7-8): 2993-3007. https://doi.org/10.1007/s00382-017-3788-5

Durre, I., Menne, M.J., Gleason, B.E., Houston, T.G. and Vose, R.S. (2010) Comprehensive automated quality assurance of daily surface observations. Journal of Applied Meteorology and Wlimatology, 49(8), 1615-1633. https://doi.org/10.1175/2010JAMC2375.1.

Eichler, T. and Higgins, W. (2006) Climatology and ENSO-related variability of North American extratropical cyclone activity. Journal of Climate, 19(10), 2076-2093. https://doi.org/10.1175/JCLI3725.1.

El-Jabi, N., Caissie, D. and Turkkan, N. (2016) Flood analysis and flood projections under climate change in New Brunswick. Canadian Water Resources Journal, 41, 319-330. https://doi.org/10.1080/07011784.2015.1071205.

Enfield, D.B., Mestas- Nunez, A.M. and Trimble, P.J. (2001) The Atlantic Multidecadal Oscillation and its relationship to rainfall and river flows in the continental U.S. Geophysical Research Letters, 28, 2077-2080. https://doi.org/10.1029/2000GL012745. 
Estilow, T.W., Young, A.H. and Robinson, D.A. (2015) A long-term Northern Hemisphere snow cover extent data record for climate studies and monitoring. Earth System Science, 7, 137-42. https://doi.org/10.5194/essd-7-137-2015.

Fazzini, M., Fratianni, S., Biancotti, A. and Billi, P. (2004) Skiability conditions in several skiing complexes on Piedmontese and Dolomitic alps. Meteorologische Zeitschrift 13(3), 253-258. https://doi.org/10.1127/0941-2948/2004/0013-0253.

Folland, C.K. (1988) Numerical models of the raingauge exposure problem, field experiments and an improved collector design. Quarterly Journal of the Royal Meteorological Society, 114, 14851516.

Fortin, G., Acquaotta, F. and Fratianni, S. (2017) The evolution of temperature extremes in the Gaspé Peninsula, Quebec, Canada (1974-2013). Theoretical and Applied Climatology, 130 (1-2), 163-172. https://doi.org/10.1007/s00704-016-1859-x.

Fortin, G. and Hétu, B. (2014) Estimating winter trends in climatic variables in the Chic Chocs Mountains, Canada (1970-2009). International Journal of Climatology, 34, 3078-3088. https://doi.org/10.1002/joc.3895.

Fortin, G. (2010) Variabilité et fréquence des cycles de gel- dégel dans la région de Québec, 19772006. The Canadian geographer, 54(2), 196-208. https://doi.org/10.1111/j.1541-0064.2009.00291.x Fratianni, S., Terzago, S., Acquaotta, F., Faletto, M., Garzena, D., Prola, M. C. and Barbero, S. 2015) How snow and its physical properties change in a changing climate alpine context? Engineering Geology for Society and Territory, 1, 57-60. https://doi.org/10.1007/978-3-319-09300$0 \_11$.

Giaccone, E., Colombo, N., Acquaotta, F., Paro, L., and Fratianni, S. (2015) Climate variations in a high altitude Alpine basin and their effects on a glacial environment (Italian Western Alps). Atmosfera, 28, 117-128. https://doi.org/10.1016/S0187-6236(15)30004-7.

Goodison, B.E. (1978) Accuracy of Canadian snow gage measurements. Journal of Applied Meteorology, 17(10), 1542-1548.

Groenewoud, H. (1984) The climatic regions of New Brunswick: a multivariate analysis of meteorological data. Canadian Journal of Forest Research, 14, 389-394. 
Groleau, A., Mailhot, A. and Talbot, G. (2007) Trend analysis of winter rainfall over southern Québec and New Brunswick (Canada). Atmosphere-Ocean, 45 (3), 153-162. https://doi.org/10.3137/ao.450303.

Guenzi, D., Acquaotta, F., Garzena, D. and Fratianni, S. (2017) CoRain: A free and open source software for rain series comparison. Earth Science Informatics. 1-12. https://doi.org/10.1007/s12145-017-0301-y.

Göktürk, O. M., Bozkurt, D., Şen, Ö. L., and Karaca, M. (2008). Quality control and homogeneity of Turkish precipitation data. Hydrological Processes: An International Journal, 22(16), 3210-3218.

Hantel, M., Ehrendorfer, M. and Haslinger, A. (2000) Climate sensitivity of snow cover duration in Austria. International Journal of Climatology: A Journal of the Royal Meteorological Society, 20(6), 615-640. $\quad$ https://doi.org/10.1002/(SICI)1097-0088(200005)20:6<615::AID-

JOC489>3.0.CO;2-0.

Hiemstra, C.A., Liston, G.E. and Reiners W.A. (2006) Observing, modelling, and validating snow redistribution by wind in a Wyoming upper treeline landscape. Ecological Modelling, 197(1-2), 3551. https://doi.org/10.1016/j.ecolmodel.2006.03.005.

Hiemstra, P. and Hiemstra, M. P. (2013). Package 'automap'. Compare 105:10.

IPCC (2014) Topic 1: Cryosphere. In Climate Change 2014: Synthesis Report. Contribution of Working Groups I, II and III to the Fifth Assessment Report of the Intergovernmental Panel on Wlimate Change [Core Writing Team, R.K. Pachauri and L.A. Meyer (eds.)]. Geneva, Switzerland, $151 \mathrm{pp}$.

Irannezhad, M., Ronkanen, A.K., Kiani, S., Chen, D. and Kløve, B. (2017) Long-term variability and trends in annual snowfall/total precipitation ratio in Finland and the role of atmospheric circulation patterns. Cold Regions Science and Technology, 143, 23-31. https://doi.org/10.1016/j.coldregions.2017.08.008.

Isotta, F.A., Frei, C., Weilguni, V., Perčec Tadić, M., Lassegues, P., Rudolf, B., Pavan, V., Cacciamani, C., Antolini, G., Ratto, S.M., Munari, M., Micheletti, S., Bonati, V., Lussana, C., Ronchi, C., Panettieri, E., Marigo, G. and Vertačnik G. (2014) The climate of daily precipitation in the Alps: Development and analysis of a high- resolution grid dataset from pan- Alpine raingauge data. International Journal of Climatology, 34(5), 1657-1675. https://doi.org/10.1002/joc.3794. 
Juřicová, A. and Fratianni, S. (2018) Climate change and its relation to the fluctuation in glacier mass balance in the Cordillera Blanca, Peru: A review. Acta Universitatis Carolinae, Geographica 53(1), 106-11.

Kelly, R.E.J., Chang, A.T.C., Tsang, L. and Foster, J.L. (2003). A prototype AMSR- E global snow area and snow depth algorithm. IEEE Transactions on Geoscience and Remote Sensing 41(2), 230242. https://doi.org/10.1109/TGRS.2003.809118.

Kim, D., Kang, S.M., Shin, Y. and Feldl, N. (2018) Sensitivity of polar amplification to varying insolation conditions. Journal of Climate, 31(12), 4933-4947. https://doi.org/10.1175/JCLI-D-170627.1.

Klein Tank, A.M.G., Zwiers, F.W. and Zhang, X. (2009) Guidelines on analysis of extreme in a changing climate in support of informed decisions for adaptation. Climate data and monitoring. WCDMP-No. 72, WMO-TD No.1500, 56 pp.Laternser, M. and Schneebeli, M. (2003). Long- term snow climate trends of the Swiss Alps (1931-99). International Journal of Climatology, 23(7), 733750. https://doi.org/10.1002/joc.912.

Kunkel, K.E., Robinson, D.A., Champion, S., Yin, X., Estilow, T. and Franksonet R.,M. (2016) Trends and Extremes in Northern Hemisphere Snow Characteristics. Current Climate Change Report, 2, 65-73. https://doi.org/10.1007/s40641-016-0036-8.

Lee, D., Ward, P.J. and Block, P. (2018) Identification of symmetric and asymmetric responses in seasonal streamflow globally to ENSO phase. Environmental Research Letters, 13(4). https://doi.org/10.1088/1748-9326/aab4ca.

Liu, Z., Tang, Y., Jian, Z., Poulsen, C.J., Welker, J.M. and Bowen, G.J. (2017) Pacific North American circulation pattern links external forcing and North American hydroclimatic change over the past millennium. Proceedings of the National Academy of Sciences, 114(13), 3340-3345. https://doi.org/10.1073/pnas.1618201114.

Mallet, J., Fortin, G. and Germain, D. (2017) Extreme weather events in northeastern New Brunswick (Canada) for the period 1950-2012: Comparison of newspaper archive and weather station data. The Canadian Geographer, 62(2), 1-14. https://doi.org/10.1111/cag.12411.

Marcolini, G., Bellin, A., Disse, M. and Chiogna, G. (2017) Variability in snow depth time series in the Adige catchment. Journal of Hydrology: Regional Studies, 13, 240-254. https://doi.org/10.1016/j.ejrh.2017.08.007. 
Mekis, É. and Vincent, L.A. (2011) An overview of the second generation adjusted daily precipitation dataset for trend analysis in Canada. Atmosphere-Ocean, 49, 163-177. https://doi.org/10.1080/07055900.2011.583910.

Mekis, É. and Brown, R. (2010) Derivation of an adjustment factor map for the estimation of the water equivalent of snowfall from ruler measurements in Canada. Atmosphere-Ocean, 48, 284293. https://doi.org/10.3137/AO1104.2010.

Milewska, E.J. and Vincent, L.A. (2016) Preserving continuity of long-term daily maximum and minimum temperature observations with automation of reference climate stations using overlapping data and meteorological conditions. Atmosphere-Ocean, 54(1), 32-47. https://doi.org/10.1080/07055900.2015.1135784.

Min, S-K., Zhang, X. and Zwiers, F. (2008) Human-induced arctic moistening. Science 320, 518520. https://doi.org/10.1126/ Science. 1153468.

Mott, R., Lehning, M., Daniels, M. and Lehning, M. (2015). Atmospheric flow development and associated changes in turbulent sensible heat flux over a patchy mountain snow cover. Journal of Hydrometeorology, 16 (3), 1315-1340. https://doi.org/10.1175/JHM-D-14-0036.1.

Mudryk, L.R., Kushner, P.J., Derksen, C. and Thackeray, C. (2017) Snow cover response to temperature in observational and climate model ensembles. Geophysical Research Letters, 44, 919926. https://doi.org/10.1002/2016GL071789.

Murara, P., Acquaotta, F., Garzena, D. and Fratianni, S. (2018) Daily precipitation extremes and their variations in the Itajaí River Basin, Brazil. Meteorology and Atmospheric Physics, 1-12. https://doi.org/10.1007/s00703-018-0627-0.

Olthof, I. (2017). Mapping seasonal inundation frequency (1985-2016) along the St-John River, New Brunswick, Canada using the Landsat archive. Remote Sensing, 9(2), 143. https://doi.org/10.3390/rs9020143

Pithan, F., and Mauritsen, T. (2014) Arctic amplification dominated by temperature feedbacks in contemporary climate models. Nature Geoscience, 7, 181-184. https://doi.org/10.1038/ngeo2071.

Nigrelli, G., Fratianni, S., Zampollo, A., Turconi, L. and Chiarle, M. (2018). The altitudinal temperature lapse rates applied to high elevation rockfalls studies in the Western European Alps. Theoretical and Applied Climatology, 131, 1479-1491. https://doi.org/10.1007/s00704-017-2066-0. 
Rasmussen, R.M., Baker, B., Kochendorfer, J., Meyers, T., Landolt, S., Fischer, A.P., Black, J., Theriault, J.M., Kucera, P., Gochis, D., Smith, C., Nitu, R., Hall, M., Ikeda, K. and Gutmann, E.(2012) How Well Are We Measuring Snow: The NOAA/FAA/NCAR Winter Precipitation Test Bed. Bulletin of the American Meteorological Society, 93, 811- 829. https://doi.org/10.1175/BAMS-D-11-00052.1.

Sabine, D.L., Morrison, S.F., Whitlaw, H.A., Ballard, W.B., Forbes, G.J. and Bowman, J. (2002) Migration behaviour of white-tailed deer under varying winter climate regimes in New Brunswick. Journal of Wildlife Management, 66, 718-728. https://doi.org/10.2307/380313.

Serreze, M.C. and Barry, R.G. (2011) Processes and impacts of Arctic amplification: A research synthesis. Global Planet. Change, 77, 85-96. doi:10.1016/j.gloplacha.2011.03.004.

Serreze, M., Bromwich, D., Clark, M., Etringer, A., Zhang, T. and Lammers, R. (2002) Large-scale hydro-climatology of the terrestrial Arctic drainage system. Journal of Geophysical Research, 108, 8160-8188. https://doi.org/10.1029/2001JD000919.

Shabbar, A. and Khandekar, M. (1996) The impact of El Nino-Southern Oscillation on the temperature field over Canada. Atmosphere-Ocean, 34, 401-416. https://doi.org/10.1080/07055900.1996.9649570.

Sospedra-Alfonso, R., Mudryk, L., Merryfield, W. J. and Derksen, C. (2014) Representation of snow in the Canadian seasonal to interannual prediction system: Part I. Initialization. Journal of Hydrometeorology. https://doi.org/10.1175/JHM-D-14-0223.1.

Suzuki R. and Shimodaira H. (2015) Package “pvclust” R topics documented, 14.

Tedesche, M.E., Fassnacht, S.R. and Meiman, P.J. (2017) Scales of snow depth variability in high elevation rangeland sagebrush. Frontiers of Earth Science, 11(3), 469-481. https://doi.org/I 10.1007/s11707-017-0662-z.

Terzago, S., Cremonin, R., Cassardo, C. and Fratianni, S. (2012) Analysis of snow precipitation during the period 2000-09 and evaluation of a MSG/SEVIRI snow cover algorithm in SW Italian Alps. Geografia Fisica e Dinamica Quaternaria, 35(1), 91-99. https://doi.org/10.4461/GFDQ.2012.35.9.

Ünal, Y., Kindap, T. and Karaca, M. (2003) Redefining the climate zones of Turkey using cluster analysis. International Journal of Climatology, 23: 1045-1055. 
Vincent, L.A., Zhang, X., Brown, R.D., Feng, Y., Mekis, E. and Milewska, E.J. (2015). Observed trends in Canada's climate and influence of low frequency variability modes. Journal of Climate, 28, 4545-60. https://doi.org/10. 1175/JCLI-D-14-00697.1.

Vincent, L.A., Wang, X.L., Milewska, E.J., Wan, H., Yang, F. and Swail, V. (2012) A second generation of homogenized Canadian monthly surface air temperature for climate trend analysis. Journal of Geophysical Research, 117, D18110. https://doi.org/10.1029/2012JD017859.

Vincent, L.A. and Mekis, E. (2006) Changes in daily and extreme temperature and precipitation indices for Canada over the twentieth century. Atmosphere-Ocean, 44(2), 177-193. https://doi.org/10.3137/ao.440205.

Vincent, L.A., Zhang, X., Bonsal, B.R. and Hogg, W.D. (2002) Homogenization of daily temperatures over Canada. Journal of Climate 15(11), 1322-1334. https://doi.org/10.1175/15200442(2002)015<1322:HODTOC>2.0.CO;2.

Wang, X.L., Xu, H., Qian, B., Feng, Y. and Mekis, E. (2017) Adjusted Daily Rainfall and Snowfall Data for Canada Atmosphere - Ocean, 55 (3), pp. 155-168. https://doi.org/10.1080/07055900.2017.1342163.

Wang, X.L., Chen, H., Wu, Y., Feng, Y. and Pu, Q. (2010). New techniques for the detection and adjustment of shifts in daily precipitation data series. Journal of Applied Meteorology and Climatology, 49(12), 2416-2436. https://doi.org/10.1175/2010JAMC2376.1.

Vang, X.L., Wan, H. and Swail, V.R. (2006) Observed changes in cyclone activity in Canada and their relationships to major circulation regimes. Journal of Climate, 19, 896-915. https://doi.org/10.1175/JCLI3664.1.

Warren, F.J. and Lemmen, D.S. (2014) Canada in a changing climate: sector perspectives on impacts and adaptation. Government of Canada, Ottawa.

Wegmann, M., Orsolini, Y., Dutra, E., Bulygina, O., Sterin, A., Brönnimann, S. (2017) Eurasian snow depth in long-term climate reanalyses. The Cryosphere, 11, 923-935. https://doi.org/10.5194/tc-11-923-2017.

Yang, D., Robinson, D., Zhao, Y., Estilow, T. and Ye, H. (2003) Streamflow response to seasonal snow cover extent changes in large Siberian watersheds. Journal of Geophysical Research, 108(D18), 4578-4591. https://doi.org/10.1029/2002JD003149. 
Yang, D.Q., Goodison, B.E., Metcalfe, J.R., Louie, P., Leavesley, G., Emerson, D., Hanson, C.L., Golubev, V.S., Elomaa, E., Gunther, T., Pangburn, T., Kang, E. and Milkovic, J. (1999). Quantification of precipitation measurement discontinuity induced by windshields on national gauges, Water Resources Research, 35, 491- 508. https://doi.org/10.1029/1998WR900042.

Zhang, T., Perlwitz, J. and Hoerling, M.P. (2014) What is responsible for the strong observed asymmetry in teleconnections between El Niño and La Niña?. Geophysical Research Letters, 41(3), 1019-1025. https://doi.org/10.1002/2013GL058964.

Zhang, X., Zwiers, F. W., Hegerl, G. C., Lambert, F. H., Gillett, N. P., Solomon, S., Peter, A.S. and Nozawa, T. (2007) Detection of human influence on twentieth-century precipitation trends. Nature 448, 461-465. https://doi.org/10.1038/nature06025.

Zhong, X., Zhang, T., Kang, S., Wang, K., Zheng, L., Hu, Y. and Wang, H. (2018) Spatiotemporal variability of snow depth across the Eurasian continent from 1966 to 2012. The Cryosphere, 12(1), 227-245. https://doi.org/10.5194/tc-12-227-2018. 


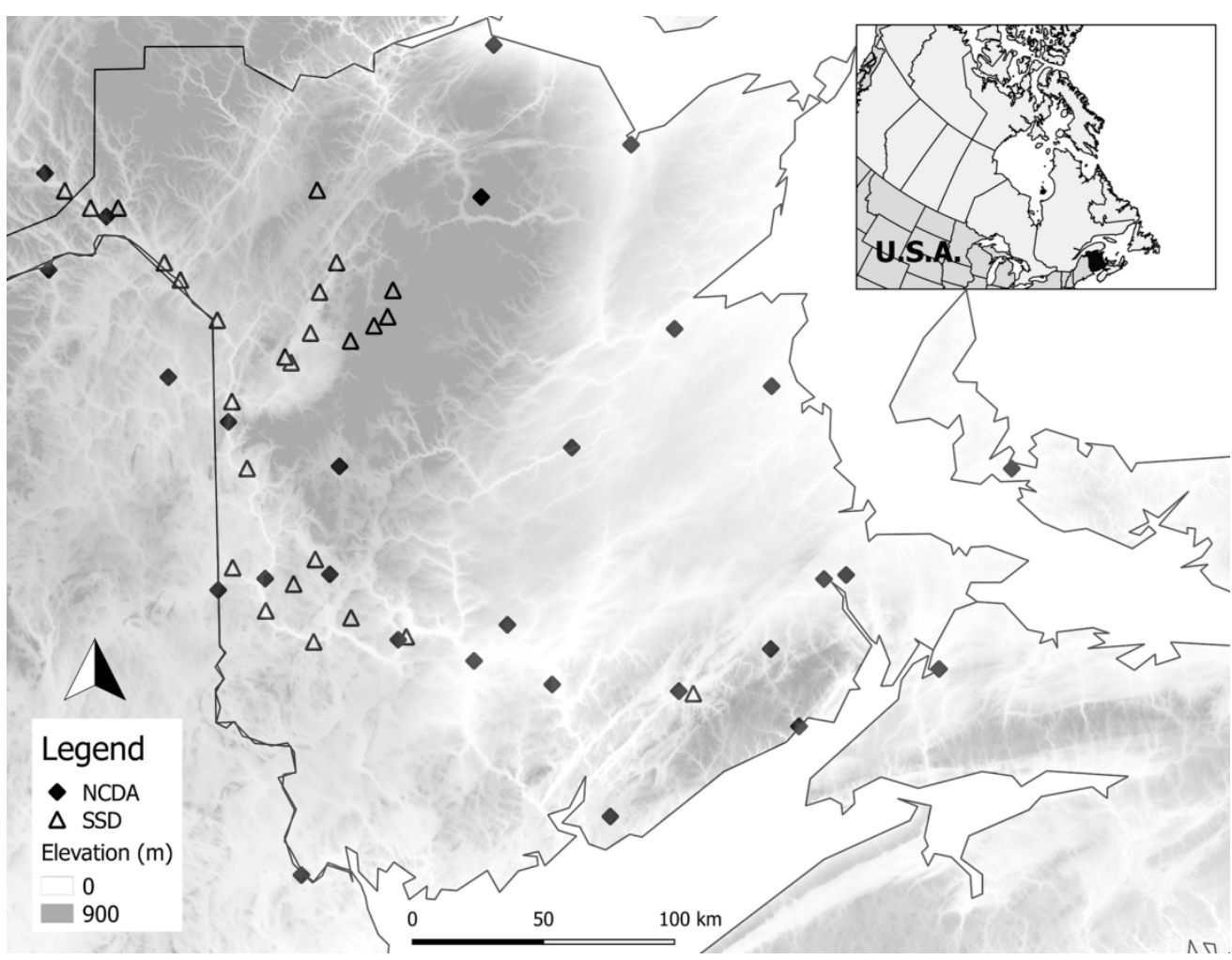

Figure 1:Study area and location of the meteorological stations used in this study in the New Brunswick region (Canada). The selected stations belong to the Snow Survey Database (SSD) and National Climate Data Archive (NCDA). SSD are represented as triangle and they are 30, while NCDA station are 30 and they are shown as black rhombus. The Digital Elevation Model ranges between 0-900 m a.s.l.

$$
79 \times 61 \mathrm{~mm}(600 \times 600 \mathrm{DPI})
$$




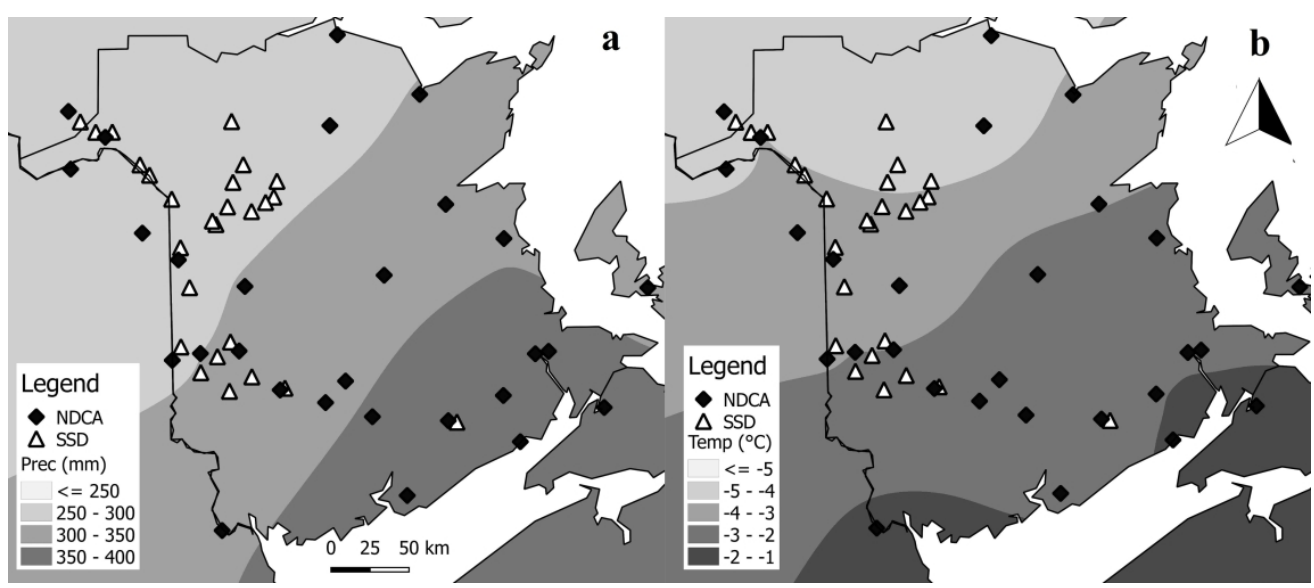

Figure 2: Spatial interpolation of 30 NCDA (triangles) and 30 SSD (rhombus) stations during the 1981-2010 reference period. a) Annual rainfall ranging between $\leq 250-400 \mathrm{~mm}$ (b) Annual mean temperature ranging between $\leq-5$ and $-1^{\circ} \mathrm{C}$.

$159 \times 69 \mathrm{~mm}(600 \times 600 \mathrm{DPI})$

This article is protected by copyright. All rights reserved. 


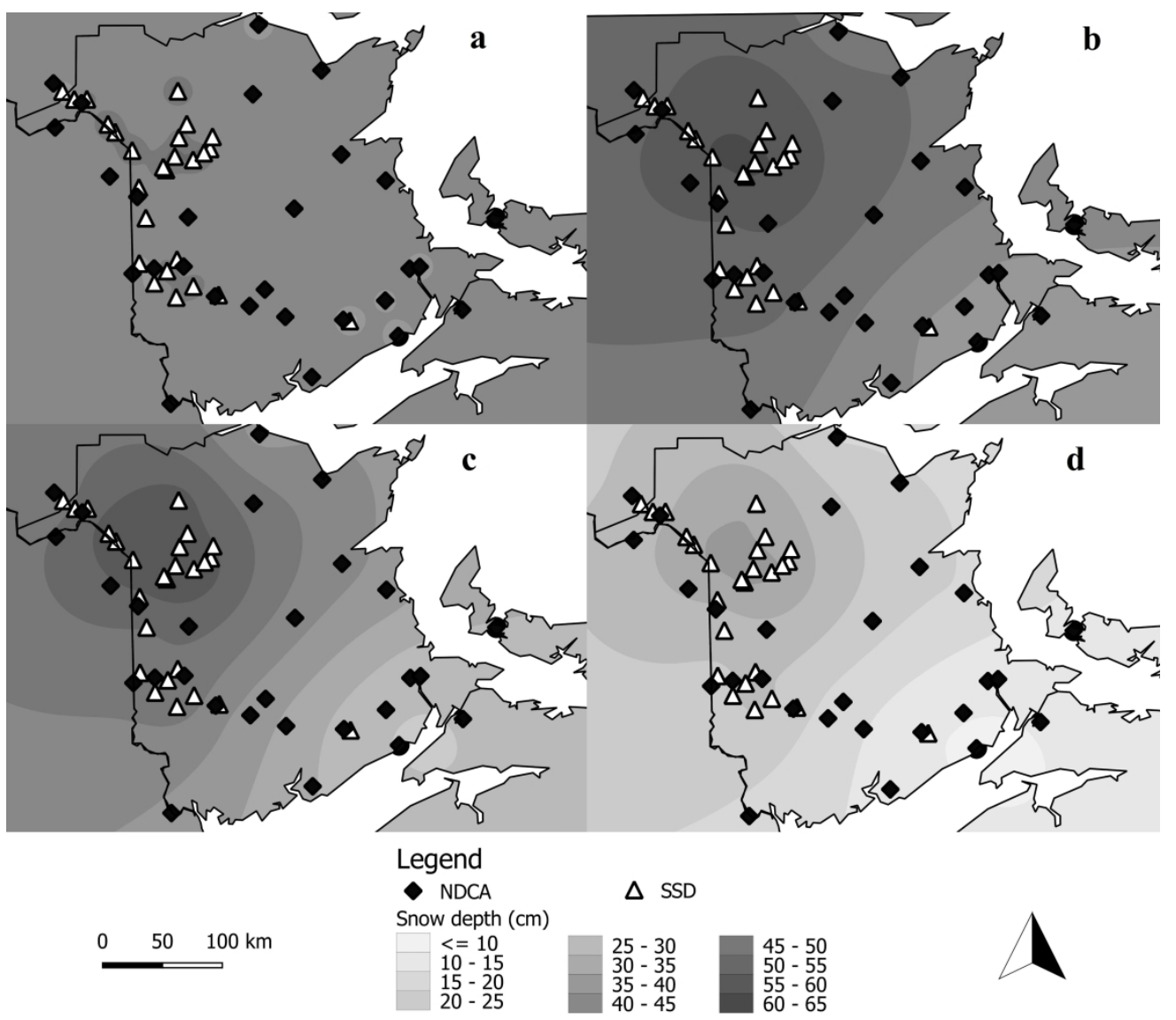

Figure 3: Spatial interpolation of 30 NCDA (triangles) and 30 SSD (rhombus) stations of annual snow depth in (a) January, (b) February, (c) March, (d) April recorded during the 1981-2010 reference period. Snow depth ranges between $\leq 10-65 \mathrm{~cm}$.

$$
159 \times 139 \mathrm{~mm}(600 \times 600 \mathrm{DPI})
$$

This article is protected by copyright. All rights reserved. 


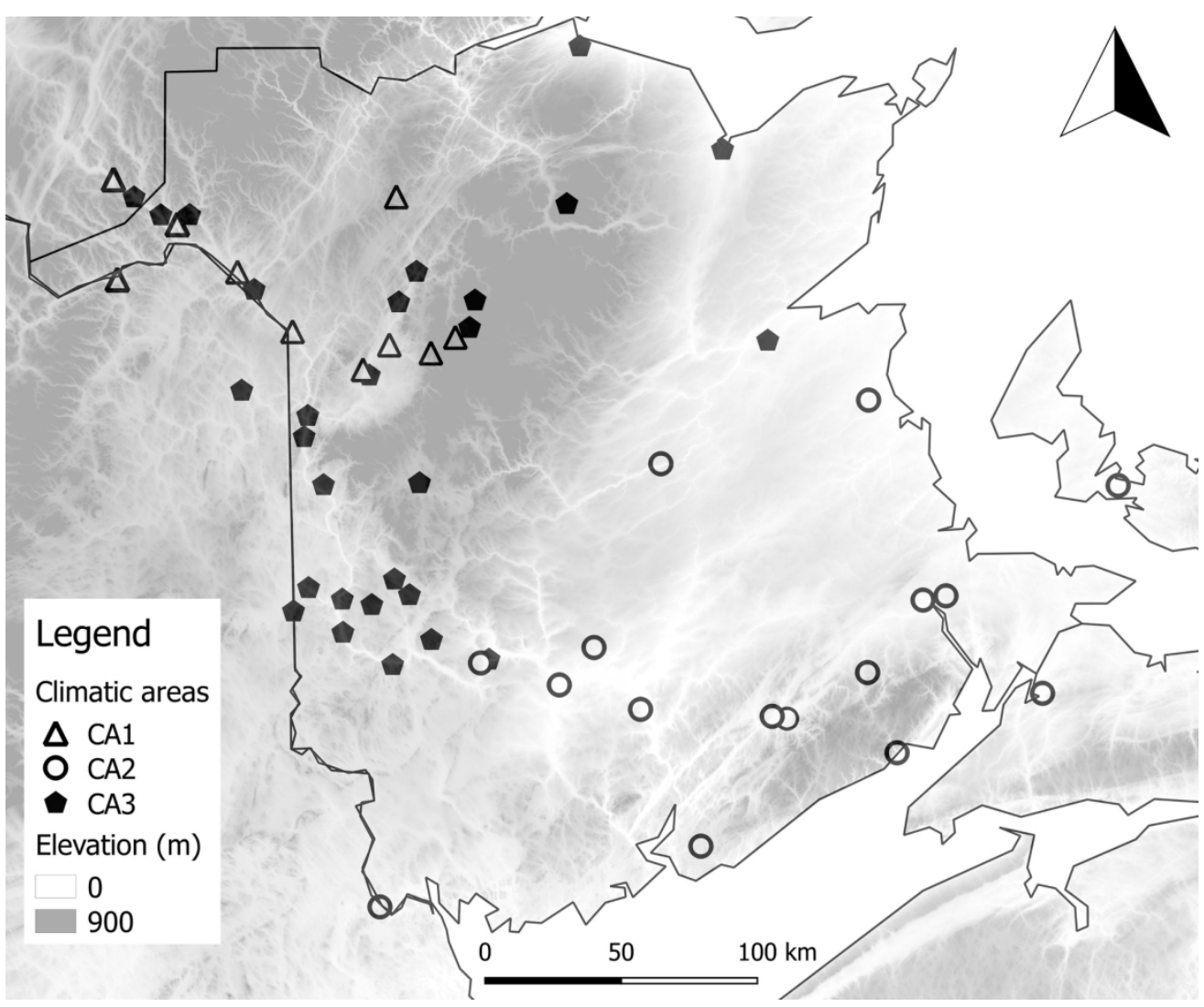

Figure 4: Classification of the New Brunswick province into three different sub-climatic areas: CA1 located at the north sector (triangles) consists of 12 stations; CA2 in the south sector (circles) composed by 18 stations; CA3 the transitional sector (pentagons) made up of 30 stations. The Digital Elevation Model ranges between 0-900 m a.s.l.

$79 \times 65 \mathrm{~mm}(600 \times 600 \mathrm{DPI})$

This article is protected by copyright. All rights reserved. 
Table 1: Climatic areas features: for each group the maximum and minimum rain, rainfall density, maximum and minimum temperature and snow depth, number of days with precipitation $>1 \mathrm{~mm}$ and snow depth trends are reported. The statistical significance of monthly snow depth trends was also highlighted. A p $=5 \%$ significance level was used for the Mann-Kendall test. In bold are reported the monthly snow depth trend statistically significant.

\begin{tabular}{|c|ccc} 
& CA1 & CA2 & CA3 \\
\hline Rain max (mm) & 389.8 & 464.2 & 331.3 \\
Rain min (mm) & 234.7 & 329.0 & 251.0 \\
Rain density (mm/day) & 7.7 & 9.5 & 9.0 \\
$\operatorname{Tmax}^{\left({ }^{\circ} \mathbf{C}\right)}$ & -1.1 & 1.8 & 0.1 \\
Tmin $\left({ }^{\circ} \mathbf{C}\right)$ & -12.3 & -8.5 & -10.8 \\
Snow depth max (cm) & 60.3 & 25.8 & 60.5 \\
Snow depth min (cm) & 70.9 & 12.6 & 20.5 \\
n. snowy days January & 8 & 6 & 7 \\
n. snowy days February & 6 & $\mathbf{6}$ & 5 \\
n. snowy days March & 5 & 5 & $\mathbf{3}$ \\
n. snowy days April & $\mathbf{3}$ & $\mathbf{2}$ &
\end{tabular}


Table 2: Daily snow depth threshold (HS) that characterise a suspicious event (95th), and the daily maximum (Tmax), minimum (Tmin) and rainfall (Rain) range that characterise a snow fall event during the cold season months (January-February) for each climatic area

\begin{tabular}{|c|c|c|c|c|c|c|c|}
\hline & & \multirow{2}{*}{ HS (cm) } & \multicolumn{2}{|c|}{$\operatorname{Tmax}\left({ }^{\circ} \mathbf{C}\right)$} & \multicolumn{2}{|c|}{$\operatorname{Tmin}\left({ }^{\circ} \mathrm{C}\right)$} & \multirow{2}{*}{ Rain $(\mathrm{mm})$} \\
\hline & & & Max & Min & Max & Min & \\
\hline \multirow{4}{*}{ CA1 } & January & 108.7 & -6.7 & -13.0 & -16.8 & -26.5 & 0 \\
\hline & February & 137.4 & -4.0 & -9.0 & -12.0 & -16.8 & 0 \\
\hline & March & 160.0 & -2.3 & -3.5 & -13.0 & -14.0 & 0 \\
\hline & April & 144.7 & 1.5 & -1.3 & -5.2 & -8.3 & 0 \\
\hline \multirow{4}{*}{ CA2 } & January & 46.0 & -1.5 & -6.5 & -10.0 & -19.0 & 0 \\
\hline & February & 67.1 & -1.0 & -4.5 & -6.0 & -14.4 & 0 \\
\hline & March & 70.0 & 2.8 & -0.7 & -1.9 & -6.5 & 0 \\
\hline & April & 47.8 & 4.0 & 1.0 & -2.0 & -3.8 & 0 \\
\hline \multirow{4}{*}{ CA3 } & January & 85.0 & -3.6 & -8.2 & -13.0 & -21.5 & 0 \\
\hline & February & 90.0 & -2.0 & -8.0 & -7.5 & -15.5 & 0 \\
\hline & March & 85.0 & -0.3 & -3.0 & -3.8 & -10.0 & 0 \\
\hline & April & 55.0 & 3.0 & 0.0 & -0.7 & -6.1 & 0 \\
\hline
\end{tabular}


Table 3: Extreme events climatic features recorded in the quality controlled automatic station in CA3: Woodstock. Tmax $=$ maximum temperature $\left({ }^{\circ} \mathrm{C}\right), \operatorname{Tmin}=\operatorname{minimum}$ temperature $\left({ }^{\circ} \mathrm{C}\right)$ and Prec $=$ liquid precipitation $(\mathrm{mm}), \mathrm{HS}=$ snow depth $(\mathrm{cm})$ and $\Delta \mathrm{HS}=$ daily snow depth difference $(\mathrm{cm})$. In light grey are the suspicious episodes.

\begin{tabular}{|c|c|c|c|c|c|c|}
\hline & & Tmax & Tmin & Prec & HS & $\Delta \mathrm{HS}$ \\
\hline \multirow[t]{4}{*}{ January } & $01 / 24 / 1981$ & -2.5 & -12.0 & 0 & 90 & 5 \\
\hline & $01 / 06 / 1986$ & -7.0 & -14.0 & 0 & 105 & 25 \\
\hline & $01 / 19 / 1987$ & -6.0 & -21.5 & 0 & 89 & 12 \\
\hline & 01/18/1994 & -5.5 & -17.0 & 0 & 92 & 44 \\
\hline \multirow[t]{3}{*}{ February } & $02 / 10 / 1982$ & -5.5 & -9.5 & 0 & 95 & 10 \\
\hline & $02 / 01 / 1987$ & -5.5 & -16.0 & 0 & 96 & 11 \\
\hline & $02 / 24 / 2009$ & -4.0 & -8.5 & 0 & 120 & 30 \\
\hline \multirow[t]{5}{*}{ March } & $03 / 06 / 2003$ & -7.5 & -12.0 & 0 & 87 & 25 \\
\hline & $03 / 09 / 2003$ & 3.0 & -7.0 & 2 & 86 & 2 \\
\hline & $03 / 02 / 2008$ & -4.5 & -8.5 & 0 & 90 & 22 \\
\hline & $03 / 13 / 2008$ & -5.5 & -13.5 & 0 & 89 & 9 \\
\hline & 03/20/2008 & -2.0 & -4.0 & 2 & 87 & 2 \\
\hline \multirow[t]{3}{*}{ April } & 04/08/1982 & -3.5 & -7.5 & 0 & 65 & 20 \\
\hline & $04 / 01 / 2001$ & 0.0 & -6.0 & 0 & 72 & 27 \\
\hline & $04 / 01 / 2008$ & 8.5 & -1.0 & 9.4 & 78 & 8 \\
\hline
\end{tabular}

This article is protected by copyright. All rights reserved. 
Table 4: Characteristics of the selected stations in CA3, Becaguimec (BECB3) is the quality controlled manual station. Mapleton (6197), Woodstock (6286) and Gibson Millstream (GIBB3) are the nearby stations. $\mathrm{ID}=$ code of the station, $\mathrm{E}=$ elevation expressed in meters, $\mathrm{Asp}=\mathrm{Aspect}, \mathrm{D}=$ distance of the nearby station to Becaguimec expressed in kilometres and $\mathrm{L}=$ location.

\begin{tabular}{|c|c|c|c|c|c|c|}
\hline & ID & Type & $\mathbf{E}(\mathbf{m})$ & Asp & $\mathrm{D}(\mathrm{Km})$ & $\mathbf{L}$ \\
\hline Becaguimenc & BECB3 & Manual & 137 & S & 0 & Forest \\
\hline Mapleton & 6197 & Automatic & 167.6 & $\mathrm{~S}$ & 8 & Forest \\
\hline Woodstock & 6286 & Automatic & 153 & $\mathrm{SE}$ & 18 & Along the forest \\
\hline Gibson & & & & & & \\
\hline Millstream & GIBB3 & Manual & 90 & SE & 20 & Forest \\
\hline
\end{tabular}


Table 5: Snow depth values recorded in the nine observed extreme events in Becaguimec (BECB3), and the neighbouring stations: Mapleton (6197), Woodstock (6286) and Gibson Millstream (GIBB3). DHS=difference of snow depth (in $\mathrm{cm}$ ) observed in the extreme event with the one recorded in the surrounding station. Highlighted in light grey are the outliers.

\begin{tabular}{|c|c|c|c|c|c|}
\hline \multicolumn{2}{|c|}{ Snow Depth Values } & BECB3 & 6197 & 6286 & GIBB3 \\
\hline \multirow[t]{2}{*}{ January } & \multirow[t]{2}{*}{$01 / 31 / 1981$} & 84.6 & NA & 80 & 63 \\
\hline & & DHS & NA & 4.6 & 21.6 \\
\hline & $01 / 31 / 1998$ & 87.1 & 79 & 100 & 72.1 \\
\hline & & DHS & 8.1 & 12.9 & 15 \\
\hline \multirow[t]{2}{*}{ February } & \multirow[t]{2}{*}{$02 / 28 / 1982$} & 106.1 & NA & 120 & 89.9 \\
\hline & & DHS & NA & 14 & 16.2 \\
\hline \multirow[t]{4}{*}{ March } & \multirow[t]{2}{*}{ 03/15/1994 } & 85.9 & 70 & 64 & 77.7 \\
\hline & & DHS & 15.9 & 21.9 & 8.2 \\
\hline & \multirow[t]{2}{*}{ 03/31/2008 } & 85.1 & NA & 80 & 71.1 \\
\hline & & DHS & NA & 5.1 & 14.8 \\
\hline \multirow[t]{6}{*}{ April } & \multirow[t]{2}{*}{ 04/14/1982 } & 56.9 & 35 & 28 & 59.7 \\
\hline & & DHS & 21.9 & 28.9 & 2.8 \\
\hline & \multirow[t]{2}{*}{$04 / 14 / 1995$} & 69.6 & 5 & 0 & 30.1 \\
\hline & & DHS & 64.6 & 64.6 & 49.5 \\
\hline & \multirow[t]{2}{*}{$04 / 14 / 2008$} & 73.7 & NA & 22 & 40.8 \\
\hline & & DHS & NA & 51.7 & 32.9 \\
\hline
\end{tabular}

This article is protected by copyright. All rights reserved. 
Table 6: Extreme events climatic features observed in the two automatic stations Mapleton (6197) and Woodstock (6286). Tmax $=$ maximum temperature $\left({ }^{\circ} \mathrm{C}\right)$, Tmin $=$ minimum temperature $\left({ }^{\circ} \mathrm{C}\right)$ and Prec $=$ liquid precipitation $(\mathrm{mm})$.

\begin{tabular}{|c|c|c|c|c|c|c|c|c|c|c|c|c|c|c|c|c|}
\hline & \multicolumn{4}{|c|}{ January } & \multirow{2}{*}{\multicolumn{2}{|c|}{$\begin{array}{c}\text { February } \\
28 / 02 / 1982\end{array}$}} & \multicolumn{4}{|c|}{ March } & \multicolumn{6}{|c|}{ April } \\
\hline & \multicolumn{2}{|c|}{ 01/31/1981 } & \multicolumn{2}{|c|}{$01 / 31 / 1998$} & & & \multicolumn{2}{|c|}{ 03/15/1994 } & \multicolumn{2}{|c|}{ 03/31/2008 } & \multicolumn{2}{|c|}{$04 / 14 / 1982$} & \multicolumn{2}{|c|}{$04 / 14 / 1995$} & \multicolumn{2}{|c|}{$04 / 14 / 2008$} \\
\hline & 6197 & 6286 & 6197 & 6286 & 6197 & 6286 & 6197 & 6286 & 6197 & 6286 & 6197 & 6286 & 6197 & 6286 & 6197 & 6286 \\
\hline Tmax & -7.5 & -6 & -2 & -0.5 & -2 & -6 & 3 & -1 & NA & -5 & 0 & 4.5 & 3 & 4.5 & NA & 6 \\
\hline Tmin & -18 & -24 & -5 & -8 & -8 & -13.5 & 0 & 1.8 & NA & -17.5 & -3 & -1 & 2 & 2 & NA & -1.5 \\
\hline Prec & 0 & 0 & 0 & 0 & 0 & 0 & 0 & 0 & NA & 0 & 0 & 0 & 13.6 & 13.2 & NA & 0 \\
\hline
\end{tabular}

This article is protected by copyright. All rights reserved. 